\title{
Structural Components of the Shamanic Rite of Tungusic Peoples in the Far East of Russia (on the Problem of Musical and Stylistic Specificity)
}

\author{
Svetlana V. Mezentseva* \\ Khabarovsk State Institute of Culture \\ 112 Krasnorechenskaia Str., Khabarovsk, 680045, Russia
}

Received 08.02.2016, received in revised form 12.04.2016, accepted 07.05.2016

The subject of the work is a shamanic rite of the Tungusic peoples of the Far East of Russia. The purpose of the work is to highlight the main structural components of the shamanic rite in terms of musical and stylistic content, and provide a number of unique materials collected by the author during the field work. The paper analyzes the structure and musical and stylistic features of the elements of Nanai, Udege, Oroch, Ulch shamanistic rituals, and presents the transcriptions and analysis of the audio recording of the ritual of the known Nanai shaman Gara Kisovna Geiker.

Keywords: ethnos, ethnic culture, music, shaman, shamanic rite, shamanistic ritual.

DOI: 10.17516/1997-1370-2016-9-6-1410-1418.

Research area: art history.

Among the structural components of the musical and stylistic complex of a shamanic pantheon, researchers distinguish shamanic mythopoetical genres and special shamanistic rituals. The latter had the following key functions:

- Curing of a patient for numerous ailments;

- Restoration of human vitality;

- Assistance in the success of hunting or fishing;

- Forwarding of the soul of a deceased person in "the lower world";

- Commemoration of the soul of a deceased person in seven days and one year after the funeral;

- Execution of good wishes [Solomonova, 1994: 25].
The shamanistic curing rituals, which are the subject of this research, were mostly popular among all Tungusic peoples. Curing shamanistic rituals usually consisted of several basic parts:

1. Shaman's calling spirit helpers

2. Searching for the stolen soul in the world of spirits.

3. Fighting against evil spirits, which stole the soul of the patient.

4. Going back to the human world.

Searching for the stolen soul was most often the longest part of the shamanistic ritual. The moment of fighting against evil spirits could be either long or swift. The shaman had to go back with the soul, "regained" from evil spirits, very quickly.

(C) Siberian Federal University. All rights reserved

* Corresponding author E-mail address: mezenceva-sv@ya.ru 
S.F. Karabanova, a choreography researcher of the peoples of the Far East as a historical and ethnographic source, identifies three periods in the ritual dances of the shaman during the shamanistic ritual. "The first is singing to the accompaniment of a tambourine, when the shaman sits and shakes the upper part of the body. The second is moving on the ground to the accompaniment of a tambourine. The third is an ecstatic chaotic motion of the body, rhythmically inconsistent with the accompaniment music. <...> If the first period occurs only once in the course of the ritual, and its purpose is to draw attention of the participants, to reassure them, to distract from daily affairs, the second and third periods are repeated several times" [Karabanova, 1984: 64-65].

Before the ritual everyone present helped the shaman to enter the desired psychological state by playing the tambourine, and the jingle of bells. Thus, the author of this work recorded a sample of a similar Udege genre of ngasikta ("calling"). The uniqueness of this genre is that two people play the tambourine: one strikes the membrane with a mallet, while the other one strikes the membrane and the rim of the tool with two willow sticks (one in each hand) (see example 1).

"Usually ngasikta was played before a shamanic rite. Playing with these sticks was used to raise all the ghosts of ancestors and the terrain. Perhaps, that is how the name of striking sticks - "calling sticks" - appeared: ngasikta was derived from the root ngasi that is to call, to call for" [Sheikin, 1986: 62]. This manner of playing was identified by researchers only among the Udege.

\section{Example 1}

"Ngasikta" - Udege "tuning up" of the shaman. Performers - V.T. Kialundziuga and her granddaughter A.Iu. Kialundziuga, Gvasugi village, the municipal district named after Lazo of the Khabarovsk Territory, in 2005': Sound recording and transcriptions by S.V. Mezentseva

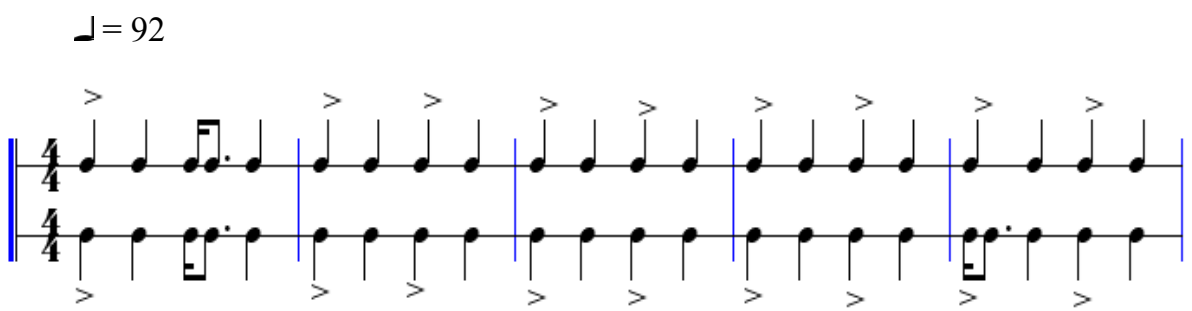

$m f$
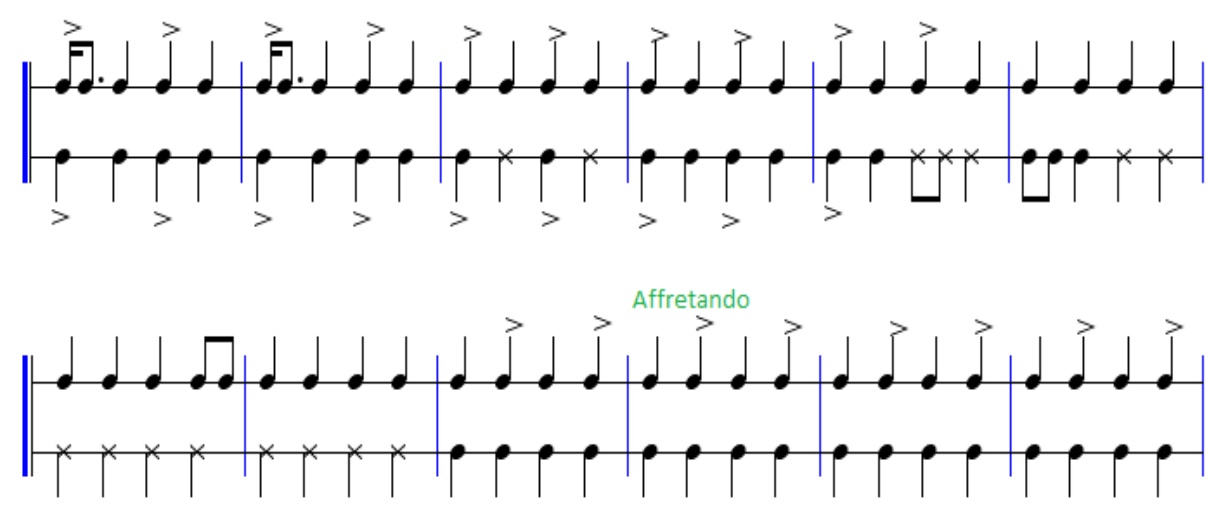


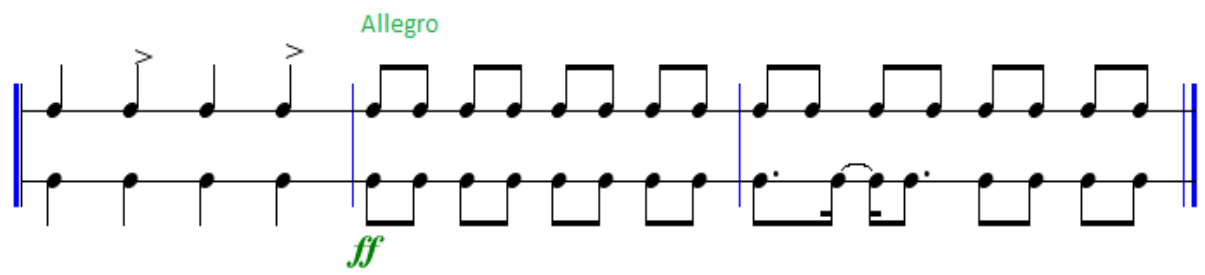

The instrumental parts of the sample we recorded form a kind of rhythmic heterophony based on dimensional alternating of quarter lengths at a moderate tempo. The dynamics and tempo suddenly grow by the end, making the performance ecstatic. During ngasikta one man was walking around the people playing the tambourine and ringing the bells (komokto), put on the fingers of both hands with the help of drawstrings ${ }^{2}$.

Example 2

Udege shamanic komokto bells.

The beginning of the XX century. From a personal collection of V.T. Kialundziuga, Gvasugi village, the municipal district named after Lazo of the Khabarovsk Territory

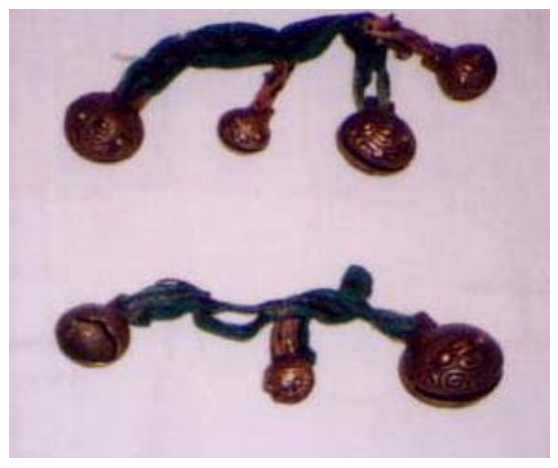

(Photo by S.V. Mezentseva)

The researchers also described the moment of «tuning up the shaman» taken from Orochs: «Before the shamanistic ritual everyone tried their hand in shamanic dances with a tambourine. This kind of introduction was usually held in a lively and funny way. Orochs said that it was an imitation of the bear's movements. This performance was called gongoini that means sonorous playing the tambourine"s.

The Ulch also had a tradition of "tuning up the shaman". At this point, everyone present took a tambourine and played in a free, relaxed manner. Different imitations and "affectations" were allowed. ${ }^{4}$

The structure of the shamanic calling for spirit helpers consists of three main parts: an appeal to spirits-helpers, a statement of a request, a description of presented gifts [Solomonova, 2000: 25]. At the beginning of the ritual slow, measured striking the tambourine with a gradual increase in tempo and dynamics sounded: "Every time the shaman begins his action with half-closed eyes, wrapped in hardly audible tambourine hum, called first by careful stroking 
the taut drumhead with the mallet's fur surface" [Steshenko-Kuftina, 1930: 100].

We recorded a sample of the Udege calling for the spirit helpers of the shaman. The words in a given sample are missing: the singer intones only separate syllables (ie - e - e) and vowels (a - a - a $)^{5}$, accompanying them with measured striking the tambourine. Gradually the dynamics enhances and the tempo of the vocal part and instrumental accompaniment accelerates:

\section{Example 3}

The Udege calling for spirit helpers of the shaman.

The performer is V.T. Kialundziuga, Gvasugi village, the municipal district named after Lazo of the Khabarovsk Territory, 2005 Sound recording and transcriptions by S.V. Mezentseva
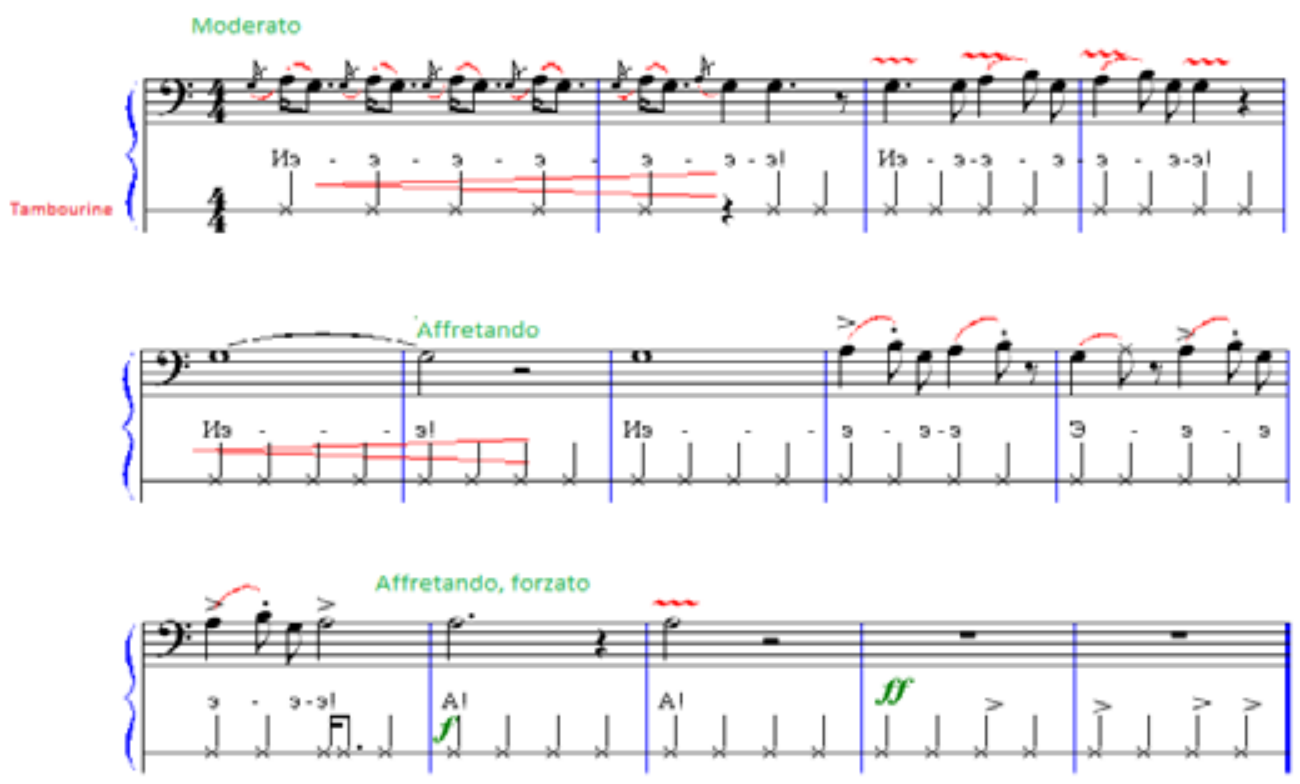

N.A. Solomonova also notes similar features of the calling for spirit helpers: «Initial singing at a slow tempo was accompanied by an even ostinato rhythmic hum of the tambourine, leading to $a$ change in the state of consciousness of the patient, and gradually becoming crescendo, reaching its peak at the moment of "spiritualizing" of the shaman. This is the first crescendo, accompanied by a vigorous background of the sounding drops on the shaman's belt, brought into the condition of a powerful ecstasy" [Solomonova, 2000: 26].

V.S. Arsen'ev gives an interesting description of the shamanistic ritual: "Hutunka [the name of the shaman - the author's note] stood before the brazier and was silent for a moment, closing his eyes, as if getting his thoughts together. $<\ldots>$ After a minute or two amidst the general silence my ear caught some sounds: Hutunka was dwelling on a note-by-note under his breath, without opening his mouth. He gradually strengthened his voice and called the spirit of "sevon", which helped him during the ritual. His singing was sad and monotonous. Little by little he came to life and shifted from foot to foot. A metallic rustle, made by spinal bones, joined the shaman's voice. Sometimes he trembled, rose on his toes and fell on his knees. His expression was very tense. He spoke broken words, begged and pleaded his 
spirit to help him. <...> He seemed to succeed in that, because his voice was more confident and even. For thirty minutes Hutunka was in the state of this trance. Gradually he lowered his tone; his singing became slow and turned into incoherent babbling. He began to dwell on one or two notes, without opening the lips, gradually going down, and completed everything with a deep sigh" [Arsen'ev, 1948: 88-89].

In the main part the shaman proceeded to implement his goals. It is important to note that the shamanistic rituals, albeit subject to certain drama, were still an improvised genre to some extent, and each shaman performed a rite in his inimitable, individual style. This seems to be a manifestation of the dialectic of tradition and individual improvisation.

In curing shamanistic rituals the shaman searched for the stolen soul of the patient, for what he went into an imaginary journey with the help of his spirit helpers and returned it to "the patient", or laid "an evil spirit" out of the patient's body. The moment of laying "an evil spirit" is characterized by "the complexity of fixing due to the specific manner of intonation - guttural sounds, tremolo, aspiration, vibrato, ekmelika, roar" [Solomonova, 2000: 26].
Sometimes the shamanistic curing rituals for infertility included lullabies, becoming a kind of hoodoo. "Such a ritual with a chant usually lasted for 2-3 hours. The text of one of the songs we recorded expressed a wish to girls - to grow well, to be able to carry water with a yoke, to sew, to pick up berries in chumashki, to boys - to grow well, quickly, to be courageous, successful hunters and fishermen. After the wishes the shaman sort of "hang" the cradle with the soul of the child on the sun's rays, rocked it through the length and breadth and this rocking pushed off all nine diseases. The shaman sang this song to the accompaniment of a tambourine" [Solomonova, 1994: 17] .

The author has transcribed a record of a shamanistic ritual of Gara Kisovna Geiker, the famous Nanai shaman? The shaman performed a shamanistic ritual to cure a young 29-year-old woman L.G. Bel'da, as she had started having severe dreams about her own funeral.

We will analyze the structure and the musical and stylistic features of the intonation of this ritual:

\section{Part I. Calling spirit helpers}

The shaman begins a ritual sitting. Swaying in a very slow pace with measured striking the tambourine, the shaman calls for her spirit helpers:

\section{Example 4}

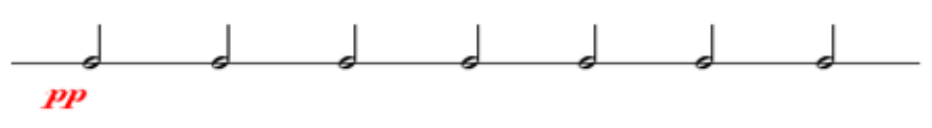

«Seperu, Iaporu, get down to my throat!

From the corner of the house, spirits, get down to my throat!»

Gradually the shaman slightly enhances the dynamics and changes the character of the rhythmic pattern of the tambourine (perhaps, these changes were caused by an appeal to the stronger spirits - Ama and Mokto Puimur) ${ }^{8}$ : 
Example 5

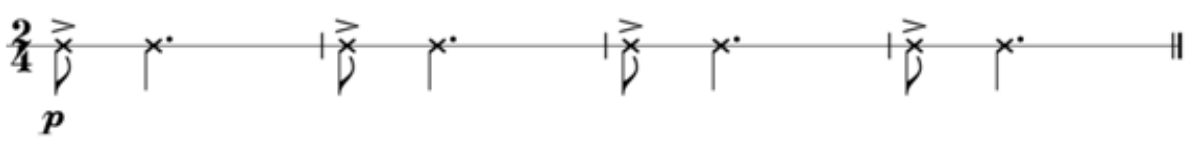

«A flock (a group) of the spirits, arrive to me from the seashore together with the Father (Ama) $)^{9}$, arrive, arrive!

Mokto Puimur, my mother, come to my Toro!"

Part II. Searching for the stolen soul.

The shaman appeals to the summoned spirits and offers them to "get hold" of an invisible thread - sonna. Tempo accelerates, dynamics increases:

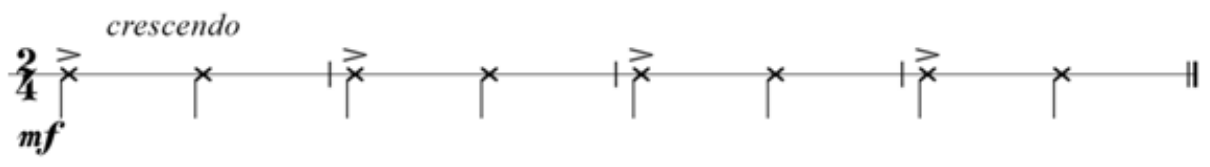

Example 6

«Fly together to find the trace,

Left after the evil spirit (Amba) had taken the woman's soul.

Fly, look for it properly!

Fly along the Amur following the scent of the evil spirit, do not miss it.

Mokto Puimur, lead the way!

Where was the soul taken? Follow the scent, do not miss it.

Quickly follow the scent!»

The shaman and her helpers reach the place where the evil spirits have been keeping the woman's soul, tormented, did something with it and took it away somewhere. The rhythm of the tambourine is "alarming", the tempo is fast, the dynamics - $\mathrm{f}$ :

Example 7

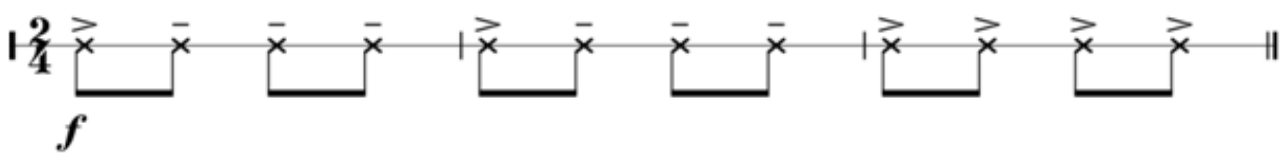

The shaman rests, then the slower tempo and smoother style of the ritual return. The shaman appeals to the spirits, asking for help:

"Help this woman, tormented by the evil spirit, so that she could recover, or at least feel better a little".

Then she went on to look for the soul.
"This woman was tormented by the ponia (the soul) of the deceased person" She strikes the tambourine loudly and appeals to the gods: "Have pity on her!"

Then she proceeds further. Along the way, she sees a hole in the ground. The shaman lists her spirit helpers and appeals to them: 


\section{"Look here properly!"}

She crept into the hole in the ground and shouts, calling spirit helpers to go with her, trying to encourage them:
"Quicker, slicker!"

Then she reached the place where the evil spirits tormented the woman (the shaman shouts loudly):

Example 8

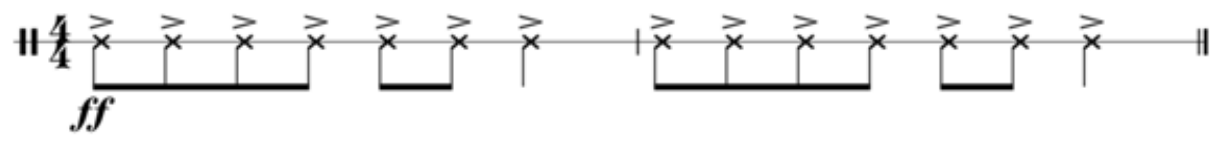

The shaman appeals to the gods to ask for help and pity for the woman. The rhythm of the tambourine changes, the dynamics fades. Then they went on their way.

Part III. Fighting against the evil spirits and return

She found the evil spirits. The shaman shouts loudly, fights against the evil spirits and tells in detail what movements she makes.

The shaman took the woman's stolen soul from the evil spirits and returns with her spirit helpers. The initial rhythm of "a step, a way, a road" returns:

Example 9

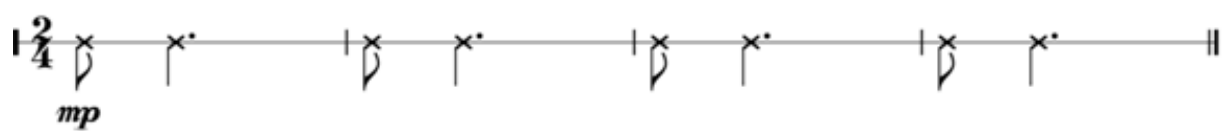

\section{Part IV}

They stopped and came up to Ene in Dekaso $^{10}$. The shaman lists the parts of the human body, where the diseases are to disappear: hands, feet, heels, etc. She gives an order to the mother (Ene) to look for the soul. Then they leave Ene - "the step rhythm" returns again.

\section{"Epili" Rite}

The shaman makes a seven that is an animal figure made of hay. She blows all bad things into it, then, this figure shall be carried out (seve nevui).

The shaman appeals to the gods, asking for help and mercy. She says that she will make a seven of hay. Then she lists the parts of the human body, from which she moves the diseases onto the seven: heart, lungs, breasts, eyes, nose, etc.

The seven is carried out, and the shaman dismisses her spirit helpers.

The author has transcribed another unique example of the Ulch shamanic hoodoo for a barren woman ${ }^{11}$. The chant is based on the variant development of the melodic formula of the monotone "whirling" of motives inside an anhemitonic tone row in the ambitus of the fifth: fis - gis - h - cis. The instrumental part (of a tambourine without drops) serves as a rhythmic accompaniment to the chant, forming a kind of rhythmic heterophony with it. This hoodoo is characterized with an uneven, "broken" rhythm, a frequent change of time: $7 / 8,5 / 8$. 
Example 10

The Ulch shamanistic hoodoo

for a barren woman

Transcriptions by S.V. Mezentseva
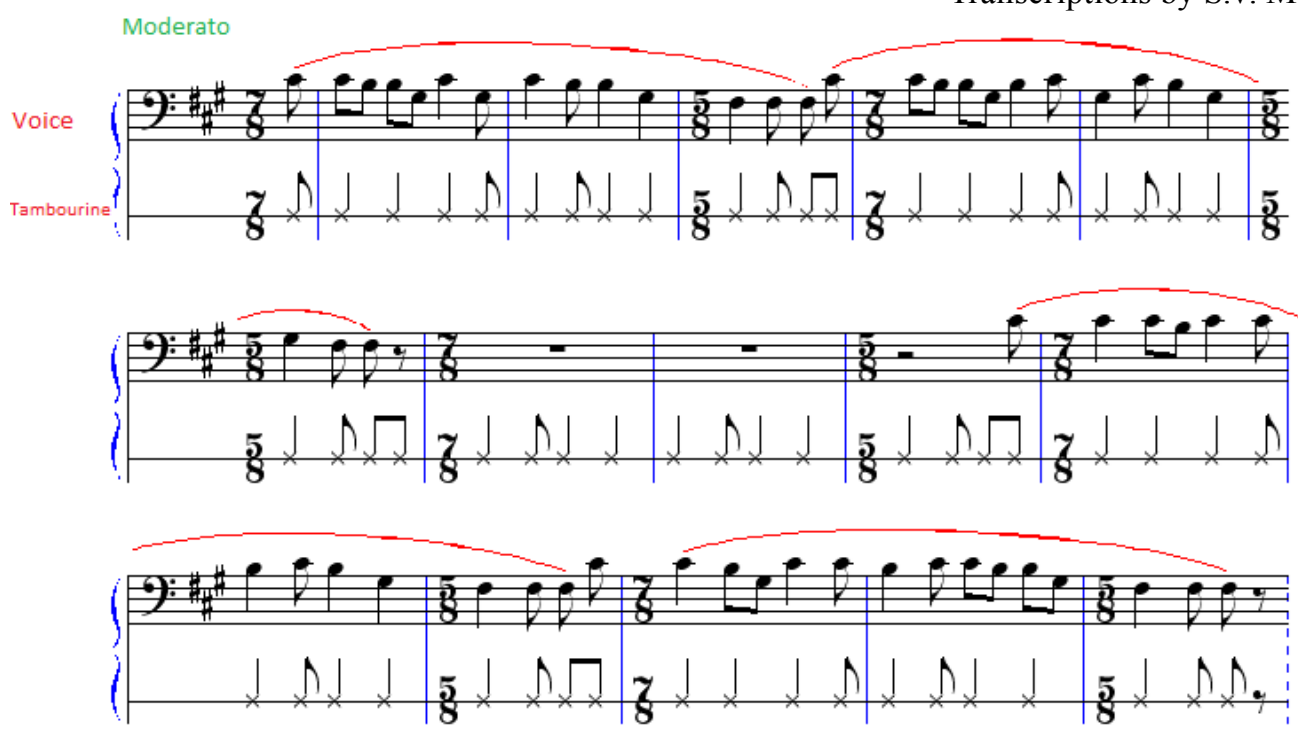

Thus, the shamanic chants and tunes, which performance can not be fixed in note recording). were part of the ritual, were characterized by As S.F. Karabanova notes, a solo improvisational deliberately harsh dynamization, underlined dance «allowed the shaman to select movements «strangeness» of the sounding, and when the and gestures in accordance with the reaction of shaman reached an ecstatic state, her motions did not subordinate to any rhythm. Improvisatoriness is a source of free, through-composed structures. Shamanic chats and tunes are dominated by those present, which in turn made them keenly and sincerely accept the content» [Karabanova, 1979: 65]. The improvisational nature, the «fluid», free structure of the rite defined the musical and stylistic contrasting dynamics, a frequent change of tempo (many nuances of vocal and instrumental features of not only a choreographic composition, but shamanic chants and tunes as well.

\footnotetext{
1 The top line is striking the tambourine with the mallet, the bottom line is striking the membrane (notes with a head) and the rim (notes with a cross) of the tambourine with two willow sticks.

2 Field data of the author. The consultant is V.T. Kialundziuga, Gvasiugi village, the municipal district named after Lazo of the Khabarovsk Territory, 2005.

3 FESAI Archives (1983), Inv. No. 322-D, 55.

4 Field data of the author. The consultant is M.S. Dechuli.

5 Perhaps, this fact testifies to the archaic nature of the sample, or was performed only one of the parts of the calling.

6 Unfortunately, the tambourine part is not given in this work.

7 The sound recording of L.G. Bel'da, translated from the Nanai language by R.A. Bel'da. The audio recording dates from February 2, 1983, Daerga village, Nanai District of the Khabarovsk Territory.

8 According to our consultant R.A. Bel'da, this rhythm means "a step, a way, a road". Field data of the author, Naikhin village, Nanai District of the Khabarovsk Territory.

$9 \quad A m a$ is a more powerful spirit.

10 Ene (mother) is the spirit guarding souls in Dekaso, that is a place where the shaman keeps souls.

11 Sound recording of P.V. Lonka repeating the voice of Sof'ia Yakovlevna Anga, born in 1915. The author expresses her gratitude to N.A. Solomonova for the provided sound recording.
} 


\section{References}

Arsen'ev, V.K. (1948). Sochineniia [Writings], 5. Vladivostok, Primizdat, 221.

Karabanova, S.F. (1979). Tantsy malykh narodov iuga Dal'nego Vostoka SSSR kak istorikoetnograficheskii istochnik [Dances of the Peoples of the South of the Far East of SSSR as a Historical and Ethnographic Source]. Moscow, Nauka, 141.

Karabanova, S.F. (1984). Shamanskie pliaski i promyslovyi obriad u narodnostei Dal'nego Vostoka SSSR [Shamanic Dances and Trade Rites of the Peoples of the Far East of SSSR], In Kul'tura narodov Dal'nego Vostoka: Traditsii i sovremennost' [Culture of the peoples of the Far East: Traditions and Modernity]. Vladivostok, DVNC AN SSSR, 147-153.

Solomonova, N.A. (2000). Muzykal'naia kul'tura narodov Dal'nego Vostoka Rossii XIX-XX vv. (Etnomuzykologicheskie ocherki): Avtoreferat dis. ... d-ra iskusstvovedeniia [Musical Culture of the Peoples of the Far East of Russia in the XIX-XX centuries (Ethnomusicological Sketches). Extended Abstract of Doctoral Thesis of Art History]. Moscow, 49.

Solomonova, N.A. (1994). Muzykal'nyi fol'klor narodnostei Nizhnego Amura i Sakhalina [Musical Folklore of the Peoples of the Lower Amur and Sakhalin]. Habarovsk, Izd-vo HGPI, 142.

Steshenko-Kuftina, V.L. (1930). Elementy muzykal'noi kul'tury paleoaziatov i tungusov [The Elements of Musical Culture of Paleasian and Tungus Peoples], In Etnografiia [Ethnography], 3, 81108.

Sheikin, Iu.I. (1986). Muzykal'nye instrumenty ude (etimologiia, konstruktsiia, naigryshi) [Musical Instruments of the Udege (Etimology, Construction, Folk Tunes], In Muzykal'noe tvorchestvo narodov Sibiri i Dal'nego Vostoka. Sb. nauchnykh trudov [Musical Art of the Peoples of Siberia and the Far East. Collection of Scientific Papers], 3. Novosibirsk, NGK im. M.I. Glinki, 38-72.

\section{Структурные компоненты шаманского обряда тунгусо-маньчжурских народов Дальнего Востока России (К проблеме музыкально-стилевой специфики)}

\section{С.В. Мезенцева}

Хабаровский государственныий институт культурь Россия, 680045, Хабаровск, ул. Краснореченская, 112

\footnotetext{
Предмет работы - шаманский обряд тунгусо-маньчжуров Дальнего Востока России. Цель работы - осветить основные структурные компоненты шаманского обряда с точки зрения музыкально-стилевого наполнения, а также представить ряд уникальных материалов, собранных автором в прочессе полевой работы. В статье анализируется структура $и$ музыкально-стилевые особенности элементов нанайских, удэгейских, орочских, ульчских шаманских камланий, приводится расшифровка и анализ аудиозаписи камлания известной нанайской шаманки Гары Кисовны Гейкер.
}

Ключевые слова: этнос, этнокультура, музыка, шаман, шаманский обряд, камлание.

Научная специиальность: 17.00.00-искусствоведение. 